\title{
Pengaruh Komposisi Molar terhadap Karakteristik dan Stabilitas Fisikokimia Komplek Inklusi Alfa Arbutin dengan Hidroksipropil Beta Siklodekstrin Menggunakan Metode Kneading
}

\author{
Elvi Setianingsih Suckristiana', Ni Luh Dewi Aryani², dan Ririn Sumiyani ${ }^{3}$ \\ ${ }^{1}$ Program Studi Magister Farmasi, Universitas Surabaya, Surabaya \\ 2 Departemen Farmasetika, Fakultas Farmasi Universitas Surabaya, Surabaya \\ ${ }^{3}$ Departemen Kimia Farmasi, Fakultas Farmasi Universitas Surabaya, Surabaya
}

Korespondensi: Elvi Setianingsih Suckristiana

Email: setianingsihelvi@gmail.com

Submitted: 07-02-2019, Revised: 25-03-2019, Accepted: 23-04-2019

\begin{abstract}
ABSTRAK: Penelitian ini bertujuan untuk mengetahui pengaruh variasi komposisi alfa arbutin dengan hidroksipropil beta siklodekstrin (HPBCD) yang dibentuk kompleks inklusi dengan menggunakan metode kneading, dibandingkan campuran fisiknya terhadap karakteristik dan stabilitasnya, yang disimpan pada suhu $40^{\circ} \pm 2^{\circ} \mathrm{C}$ dan kelembaban $75 \% \pm 5 \%$ selama 30 hari. Variasi komposisi molar alfa arbutin : HPBCD pada campuran fisik yaitu 1:1 (F1), 2:1 (F2), dan 1:2 (F3), sedangkan pada komplek inklusinya adalah 1:1 (F4), 2:1 (F5), dan 1:2 (F6). Interaksi padatan yang terbentuk pada komplek inklusi dan campuran fisik dikarakterisasi dengan morfologi, gugus fungsi, titik lebur, kadar alfa arbutin dan hidrokinon sebagai hasil urainya, serta uji disolusi. Berdasarkan hasil penelitian dapat disimpulkan bahwa telah terjadi pembentukan komplek inklusi antara alfa arbutin dengan HPBCD yang dibuat dengan metode kneading. Hasil pembentukan komplek inklusi yang paling baik secara berurutan adalah pada F6, F4, dan F5, karena memberikan perbedaan karakteristik fisikokimia secara bermakna. Komplek inklusi menunjukkan kristal amorf yang lebih homogen, kadar alfa arbutin yang lebih tinggi dan stabil $(48,32 \pm 0,10 \%)$, serta laju disolusi yang lebih cepat dengan persen terdisolusi paling tinggi dibanding formula lainnya. Tidak terjadi perubahan fisikokimia baik pada campuran fisik maupun komplek inklusinya, dan hidrokinon yang merupakan hasil urai alfa arbutin tidak terbentuk selama dilakukan uji stabilitas dipercepat.
\end{abstract}

Kata kunci: alfa arbutin; hidroksipropil beta siklodekstrin; metode kneading; karakteristik; stabilitas fisikokimia

\begin{abstract}
This study aimed to determine the effect of variations in the composition of alpha arbutin with hydroxypropyl beta cyclodextrin (HPBCD) which was formed by inclusion complex using kneading method. Inclusion complex was compared to its physical mixture on its characteristics and stability (stored at $40^{\circ} \pm 2^{\circ} \mathrm{C}$ and humidity $75 \% \pm 5 \%$ for 30 days). Variations in the molar composition of alpha arbutin : HPBCD in the physical mixture namely $1: 1$ (F1), $2: 1$ (F2) and $1: 2$ (F3), while in the inclusion complex are $1: 1$ (F4), $2: 1$ (F5) and $1: 2$ (F6). Solid interactions formed in the inclusion complex and physical mixture were characterized by morphology, functional groups, melting points, alpha arbutin and hydroquinone (as the decomposition product) concentrations, and dissolution tests. Based on the results of the study it can be concluded that there has been the formation of an inclusion complex between alpha arbutin and HPBCD made using the kneading method. The best inclusion complex sequentially are F6, F4, and F5, because it gives a significant difference in physicochemical characteristics. Inclusion complexes show more homogeneous amorphous crystals, higher and more stable alpha arbutin concentrations (48.32 \pm $0.10 \%)$, and faster dissolution rates with the highest percent dissolution compared to other formulas. There was no physicochemical change in either the physical mixture or the inclusion complex, and the hydroquinone which was a decomposition product of alpha arbutin was not formed during the accelerated stability test.
\end{abstract}

Keywords: alpha arbutin; hydroxypropyl beta cyclodextrin; kneading method; characteristics; physicochemical stability 


\section{Pendahuluan}

Alfa arbutin adalah salah satu senyawa penghambat tirosinase yang paling banyak digunakan pada sediaan kosmetik karena aman dan efektif, tetapi dapat terurai pada suhu $40^{\circ} \mathrm{C}$ dengan menghasilkan hidrokinon dari yang semula 1-3 ppm menjadi sekitar 13 ppm [1]. Penelitian sebelumnya [2], menunjukkan bahwa alfa arbutin mengalami dekomposisi mulai pada suhu $200^{\circ} \mathrm{C}$ dengan analisa Differential Scanning Calorimetry (DSC), sedangkan bentuk komplek inklusinya dengan hidroksipropil beta siklodekstrin (HPBCD) pada komposisi ratio molar (1:1) menggunakan metode freeze drying dapat meningkatkan stabilitasnya dan mulai mengalami dekomposisi pada suhu $320^{\circ} \mathrm{C}$. Penelitian tersebut membuktikan bahwa stabilitas arbutin terhadap suhu dapat ditingkatkan dengan komplek inklusi HPBCD, namun pengujian stabilitas dipercepat dan pengujian kandungan hidrokinon sebagai hasil peruraian alfa arbutin belum dilakukan.

Berdasarkan latar belakang tersebut, penelitian ini dilakukan untuk mengetahui pengaruh variasi komposisi molar terhadap karakteristik dan stabilitas fisikokimia komplek inklusi alfa arbutin dengan HPBCD. Pembentukan komplek inklusi dilakukan dengan menggunakan metode kneading, dengan variasi komposisi rasio molar (alfa arbutin : HPBCD) 1:1, 2:1 dan 1:2. Karakteristik dan stabilitas fisikokimia komplek inklusi pada berbagai variasi komposisi molar tersebut dibandingkan dengan campuran fisiknya. Komplek inklusi yang diperoleh kemudian dikarakterisasi dan dilakukan uji stabilitas dipercepat (suhu $40^{\circ} \pm 2^{\circ} \mathrm{C}$; kelembaban $75 \% \pm 5 \%$ ) selama 30 hari. Karakterisasi dan uji stabilitas yang dilakukan terdiri dari parameter fisika dan kimia yang meliputi morfologi, gugus fungsional, titik lebur, kadar alfa arbutin dan hidrokinon sebagai hasil urainya, serta uji disolusi.

\section{Bahan dan metode}

\subsection{Bahan penelitian}

Bahan-bahan yang digunakan dalam peneli- tan ini adalah alfa arbutin pharmaceutical grade 99,8\% (Thornhill, Canada) dan hidroksipropil beta siklodekstrin (HPBCD) pharmaceutical grade $\geq 98 \%$ (Shaanxi Guanjie Technology Co., Ltd). Standar yang digunakan adalah alfa arbutin HPLC grade $>99 \%$ (Sigma Aldrich) dan hidrokinon synthesis grade (Merck), sedangkan bahan kimia lain yang digunakan sebagai fase gerak adalah metanol pro HPLC (Merck), asam klorida ( $\mathrm{HCl}$ ) p.a., etanol p.a., kalium dihydrogen phospat $\left(\mathrm{KH}_{2} \mathrm{PO} 4\right)$ p.a., natrium hidroksida $(\mathrm{NaOH})$ p.a. (Merck) dan air suling.

\subsection{Peralatan penelitian}

Peralatan yang digunakan dalam penelitan ini diantaranya UPLC model Acquity Waters dan kolom BEH C18 (1,7 $\mu \mathrm{m} ; 2,1$ mm x 50 mm; Acquity UPLC®, USA), SEM (Hitachi TM 3000, Jepang), Spektrofotometer UV (Shimadzu UV-1800, Jepang), FTIR-Jasco (FTIR-4200, Jepang), DSC (Mettler Toledo, USA), climatic chamber (Bluepard, China), pH meter (Schott lab 850), timbangan analitik digital (AND seri 14227794), kertas saring nilon 0,2 $\mu \mathrm{m}, 47 \mathrm{~mm}$ (Pall), kertas saring nilon 0,2 $\mu \mathrm{m}, 13 \mathrm{~mm}$ (Whatman) dan alat-alat gelas laboratorium (pyrex).

\subsection{Pembuatan campuran fisik}

Pembuatan campuran fisik dilakukan dengan menghaluskan alfa arbutin dan HPBCD di dalam mortar menggunakan alu. Alfa arbutin dan HPBCD ditimbang sesuai formula F1, F2 dan F3 (Tabel 1).

\subsection{Pembuatan komplek inklusi alfa arbutin dengan $H P B C D$}

Pembuatan komplek inklusi dilakukan dengan menimbang alfa arbutin dengan HPBCD sesuai formula F4, F5, dan F6 (Tabel 1). HPBCD dimasukkan ke dalam mortar dan ditambahkan etanol $50 \%$ secukupnya hingga diperoleh pasta. Secara perlahan alfa arbutin dimasukkan ke dalam pasta dan diaduk menggunakan alu selama 45 menit. Campuran dikeringkan pada suhu $45^{\circ} \mathrm{C}$ selama 48 jam dalam oven, dipulverasi, dilewatkan di 
Tabel 1. Formulasi campuran alfa arbutin dengan HPBCD

\begin{tabular}{lllllll}
\hline Metode campuran & Formula & $\begin{array}{l}\text { Perbandingan } \\
\text { molar }\end{array}$ & $\begin{array}{l}\text { Alfa } \\
\text { arbutin } \\
\text { (g) }\end{array}$ & $\begin{array}{l}\text { HPBCD } \\
\text { (g) }\end{array}$ & $\begin{array}{l}\text { Berat } \\
\text { total } \\
\text { (g) }\end{array}$ & $\begin{array}{l}\text { Penimbangan } \\
\text { sampel (g) } \\
\text { untuk analisa }\end{array}$ \\
\hline $\begin{array}{l}\text { Campuran fisik } \\
\text { (kontrol) }\end{array}$ & $\mathrm{F} 1$ & $1: 1$ & 0,272 & 1,460 & 1,722 & 0,32 \\
& $\mathrm{~F} 2$ & $2: 1$ & 0,544 & 1,460 & 2,004 & 0,184 \\
\hline $\begin{array}{l}\text { Metode kneading } \\
\text { (perlakuan) }\end{array}$ & $\mathrm{F} 3$ & $1: 2$ & 0,272 & 2,920 & 3,192 & 0,59 \\
& $\mathrm{~F} 4$ & $1: 1$ & 0,272 & 1,460 & 1,722 & 0,32 \\
& $\mathrm{~F} 5$ & $2: 1$ & 0,544 & 1,460 & 2,004 & 0,184 \\
\hline & $\mathrm{F} 6$ & $1: 2$ & 0,272 & 2,920 & 3,192 & 0,59 \\
\hline
\end{tabular}

Tabel 2. Karakterisasi dan uji stabilitas dipercepat

\begin{tabular}{|c|c|c|c|c|c|}
\hline \multirow{2}{*}{ Parameter } & \multicolumn{5}{|c|}{ Instrumen } \\
\hline & SEM & FTIR & DSC & UPLC & Disolusi tipe 2 (dayung) \\
\hline \multicolumn{6}{|l|}{ Parameter fisika } \\
\hline Uji morfologi & A & & & & \\
\hline Uji gugus fungsi & & $A, B$ & & & \\
\hline Uji titik lebur & & & $A, B$ & & \\
\hline \multicolumn{6}{|l|}{ Parameter kimia } \\
\hline Uji kadar alfa arbutin dan hidrokinon & & & & $\mathrm{A}, \mathrm{B}$ & \\
\hline Uji disolusi & & & & & $\mathrm{A}, \mathrm{B}$ \\
\hline
\end{tabular}

Keterangan:

A: Parameter karakterisasi dilakukan pada hari ke-0

B: Parameter uji stabilitas dipercepat dilakukan pada hari ke-30

atas ayakan no. 100, dan disimpan dalam desikator [3].

\subsection{Karakterisasi dan uji stabilitas dipercepat}

Semua sampel baik dari campuran fisik maupun komplek inklusi (F1 - F6), dilakukan karakterisasi dan uji stabilitas dipercepat $\left(40 \pm 2^{\circ} \mathrm{C}\right.$, RH $75 \% \pm 5 \%$, 30 hari). Pengambilan sampel dilakukan pada hari ke-0 dan ke-30, sedangkan karakterisasi yang dilakukan meliputi: morfologi, gugus fungsi, titik lebur, kadar alfa arbutin, serta disolusi (Tabel 2).

\subsubsection{Uji morfologi}

Uji morfologi dilakukan dengan Scanning Electron Microscopy (SEM) pada semua sampel yang disiapkan kurang lebih 0,5 mg dan direkatkan pada sebuah perekat berupa selotip karbon. Kemudian sampel yang merekat pada selotip karbon diuji dengan dengan diberikan tekanan udara.

\subsubsection{Uji gugus fungsi}

Uji spektroskopi FTIR dilakukan pada alfa arbutin dan HPBCD murni serta sampel campuran fisik dan komplek inklusi. Masing-masing sampel dibuat pelet $(1 \mathrm{~mm})$ dengan $\mathrm{KBr}$ (2 mg sampel per 200 mg KBr kering), kemudian spektra absorban FTIR diukur pada bilangan gelombang $4000-400 \mathrm{~cm}^{-1}$.

\subsubsection{Uji titik lebur}

Penetapan titik lebur dari senyawa dalam keadaan tunggal, campuran fisik dan komplek inklusi menggunakan alat DSC. Sampel ditimbang $\pm 5 \mathrm{mg}$ dan dimasukkan dalam sel aluminum kemudian diletakkan pada wadah sampel dalam DSC. Sampel dipanaskan dengan kecepatan pemanasan $20^{\circ} \mathrm{C} /$ menit. 


\subsubsection{Uji kadar alfa arbutin dan hidrokinon}

Pengujian kadar alfa arbutin dan hidrokinon dilakukan dengan UPLC dengan persiapan sebagai berikut:

\subsubsection{Penentuan $\lambda$ maksimum}

Dibuat larutan yang mengandung $5,0 \mu \mathrm{g} / \mathrm{ml}$ alfa arbutin dan 5,0 $\mu \mathrm{g} / \mathrm{ml}$ hidrokinon dengan air suling dan dibaca absorbansinya menggunakan spektrofotometer UV-Vis pada $\lambda 200-400 \mathrm{~nm}$. Absorbansi yang diperoleh dapat digunakan untuk menentukan $\lambda$ maksimum pada pengujian alfa arbutin dan hidrokinon.

\subsubsection{Validasi metode analisa}

Validasi metode analisa dilakukan dengan menggunakan parameter linearitas, LOD dan LOQ, akurasi dan presisi, dengan sebelumnya dilakukan optimasi fase gerak dan uji kesesuaian sistem. Kurva kalibrasi dibuat menggunakan 5 konsentrasi baku yang masing-masing mengandung alfa arbutin dan hidrokinon 1,0; 3,0; 5,0; 10,0; dan 20,0 $\mu \mathrm{g} / \mathrm{ml}$. Masing-masing konsentrasi disuntikkan 3 kali, dengan volume 1,4 $\mu$ l. Kurva kalibrasi dibuat dengan memproyeksikan data perbandingan area (y) dengan konsentrasi laru$\tan (\mathrm{x})$. LOD dan LOQ dihitung dari standar deviasi (SD) dan slope dari persamaan regresi kurva baku (S), dengan perhitungan sebagai berikut: $\mathrm{LOD}=3,3(\mathrm{SD} / \mathrm{S})$ dan LOQ $=10(\mathrm{SD} / \mathrm{S})$. Pengujian akurasi dan presisi dilakukan dengan penambahan larutan standar alfa arbutin dan hidrokinon yang diketahui konsentrasinya yaitu 4,0; 6,0; dan 9,0 $\mu \mathrm{g} / \mathrm{ml}$ pada larutan sampel F5. Masingmasing larutan tersebut kemudian diinjeksikan sebanyak tiga kali dan dihitung nilai perolehan kembali dengan rumus sebagai berikut:

$$
\% \text { Perolehan }=\frac{\mathrm{Ci}-\mathrm{Cs}}{\mathrm{Cb}} \times 100 \%
$$

Keterangan:

$\mathrm{Ci}=$ Konsentrasi yang diperoleh $(\mathrm{Ci})$

$\mathrm{Cs}=$ Konsentrasi sebelum penambahan larutan standar (Cs)

$\mathrm{Cb}=$ Konsentrasi standar yang telah diketahui konsentrasinya

\subsubsection{Pengujian sampel}

Sampel F1-F6 masing-masing ditimbang (Tabel 1) dan dilarutkan dengan metanol sampai $100 \mathrm{ml}$. Masing-masing larutan tersebut dipipet $1 \mathrm{ml}$ dan ditambahkan air suling hingga 100,0 ml. Konsentrasi akhir larutan tersebut adalah 5,0 $\mu \mathrm{g} /$ $\mathrm{ml}$ alfa arbutin.

\subsubsection{Uji disolusi}

Penentuan profil disolusi komplek inklusi dan campuran fisiknya dilakukan dengan menggunakan alat disolusi tipe 2 (dayung) dengan medium disolusi larutan dapar fosfat $\mathrm{pH}$ 7,4 sebanyak 900 $\mathrm{ml}$ di tiap labu disolusi dan suhu diatur $37^{\circ} \pm 0,5^{\circ} \mathrm{C}$. Semua sampel formula F1-F6 ditimbang seperti pada tabel 1, dimasukkan pada labu disolusi dan diputar dengan kecepatan 100 rpm. Larutan disolusi dipipet sebanyak $5 \mathrm{ml}$ pada menit ke-15, 30, $45,60,120$, dan 240 dan digantikan dengan medium baru setiap kali pengambilan sampel [4]. Sampel difiltrasi dan hasil filtrasi masing-masing dipipet $1 \mathrm{ml}$ dan dimasukkan ke dalam labu ukur $100 \mathrm{ml}$, ditambahkan air suling hingga 100,0 ml dan dianalisa dengan UPLC. Hasil uji disolusi yang berupa kadar sampel diubah menjadi persentase pelepasan kumulatif tiap waktu sampling, dengan menggunakan persamaan kurva kalibrasi. Persentase pelepasan kumulatif alfa arbutin sebagai fungsi y dan waktu sampling sebagai fungsi x. Persentase pelepasan alfa arbutin pada menit tertentu dibandingkan untuk tiap-tiap formula.

\subsection{Analisis data}

Data hasil uji kadar dan disolusi diolah secara statistik menggunakan ANOVA dan dilanjutkan dengan uji beda nyata terkecil (BNT) untuk mengetahui perlakuan mana yang memberikan perbedaan [5].

\section{Hasil dan pembahasan}

\subsection{Pembuatan campuran fisik dan komplek inklusi}

Serbuk campuran fisik alfa arbutin dan HPBCD maupun komplek inklusinya yang dibuat dengan 
metode kneading tidak menunjukkan perbedaan secara visual (Gambar 1).

\subsection{Karakterisasi dan uji stabilitas dipercepat 3.2.1. Morfologi}

Uji morfologi dilakukan terhadap sampel campuran, kemudian dibandingkan dengan alfa arbutin dan HPBCD tunggal. Pengujian dilakukan dengan menggunakan SEM pada perbesaran 500 kali. Alfa arbutin berbentuk kristal jarum dan lempengan, sedangkan kristal HPBCD berbentuk bola-bola berlubang (Gambar 2).

Pada campuran fisik (Gambar 3), F1, F2, dan F3, masih ditemukan kristal alfa arbutin yang berbentuk jarum maupun lempengan dan kristal HPBCD. Morfologi untuk komplek inklusi (Gambar 3) F4, F5, dan F6, menunjukkan bahwa kristal HPBCD dan alfa arbutin tidak nampak, yang terlihat adalah kristal yang tidak beraturan (amorf). Hal ini menunjukkan bahwa komplek inklusi telah terbentuk baik pada F4, F5, maupun F6 dengan menghasilkan senyawa yang lebih amorf.
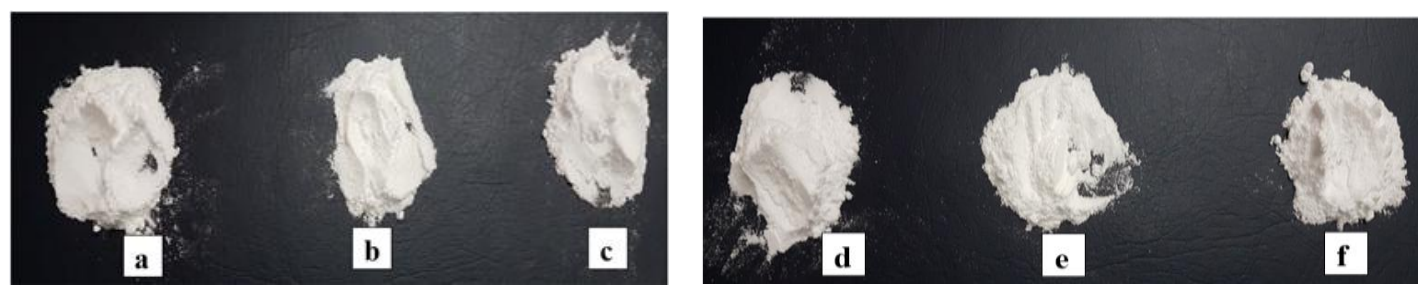

Gambar 1. Hasil serbuk campuran fisik F1 (a), F2 (b), F3 (c) dan serbuk komplek inklusi F4 (d), F5 (e), F6 (f)
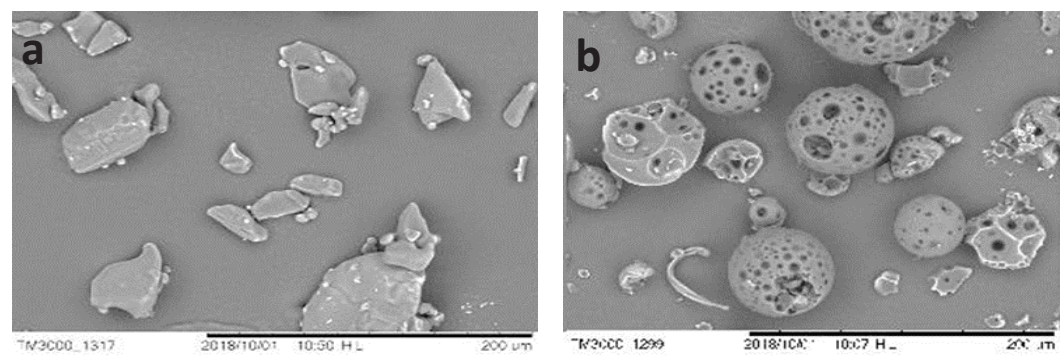

Gambar 2. Morfologi alfa arbutin (a) dan HPBCD (b) dengan perbesaran 500x
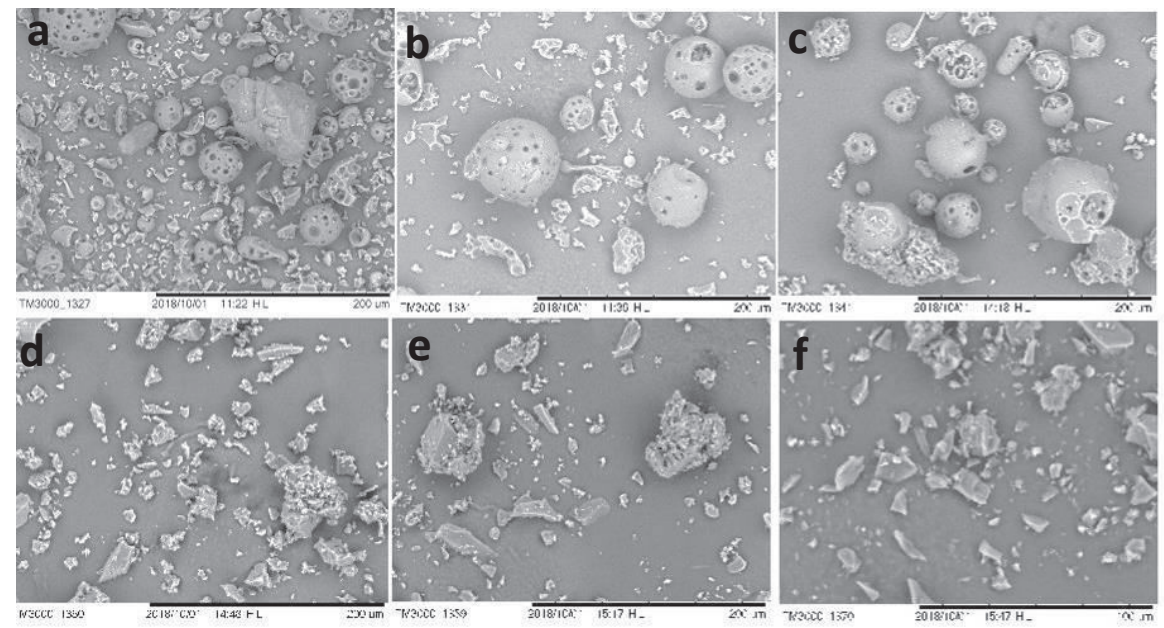

Gambar 3. Morfologi campuran fisik: F1 (a), F2 (b), F3 (c), dan komplek inklusi F4 (d), F5 (e), dan F6 (f) dengan perbesaran $500 \mathrm{x}$ 


\subsubsection{Gugus fungsi}

Identifikasi gugus fungsi dilakukan pada beberapa spektrum yang jelas dan memiliki frekuensi tepat, dengan membandingkan frekuensi serapan standar gugus fungsi [6], yaitu serapan pada $3500-3300 \mathrm{~cm}^{-1}$ adalah gugus fungsi $\mathrm{O}-\mathrm{H}$, $3000-2700 \mathrm{~cm}^{-1}$ adalah gugus fungsi $\mathrm{C}-\mathrm{H}$, dan 1820-1600 $\mathrm{cm}^{-1}$ adalah gugus fungsi $\mathrm{C}=0$. Pada Gambar 4 terlihat gugus fungsi O-H, C-H maupun $\mathrm{C}=0$ baik pada alfa arbutin maupun HPBCD.

Gambar 5 menunjukkan bahwa penambahan HPBCD mempengaruhi berkurangnya beberapa gugus $\mathrm{C}-\mathrm{H}$ dari alfa arbutin pada sampel komplek inklusi, dibandingkan sample campuran fisik, dan berkurangnya beberapa gugus $\mathrm{C}=\mathrm{O}$ dari alfa arbutin pada sampel F1 - F6 yang merupakan ciri khas dari aromatik nukleus alfa arbutin. Hal terse- but menunjukkan bahwa cincin fenil alfa arbutin terlibat dalam pembentukan komplek inklusi dan campuran fisik [2].

Spektrum FTIR sampel untuk uji stabilitas dipercepat ditunjukkan pada Gambar 6, dimana semua gugus fungsi $\mathrm{O}-\mathrm{H}, \mathrm{C}=\mathrm{O}$, dan $\mathrm{C}-\mathrm{H}$ cukup stabil pada F1-F6. Hal tersebut menunjukkan bahwa penyimpanan pada suhu $40^{\circ} \mathrm{C}$ dan kelembaban 75\% selama 30 hari tidak menyebabkan perubahan gugus fungsi baik pada campuran fisik maupun komplek inklusi.

\subsubsection{Titik Lebur}

Hasil thermogram DSC pada Gambar 7 menunjukkan bahwa alfa arbutin mulai mengalami dekomposisi pada suhu $205^{\circ} \mathrm{C}$, sedangkan HPBCD mulai mengalami dekomposisi pada suhu $318^{\circ} \mathrm{C}$.

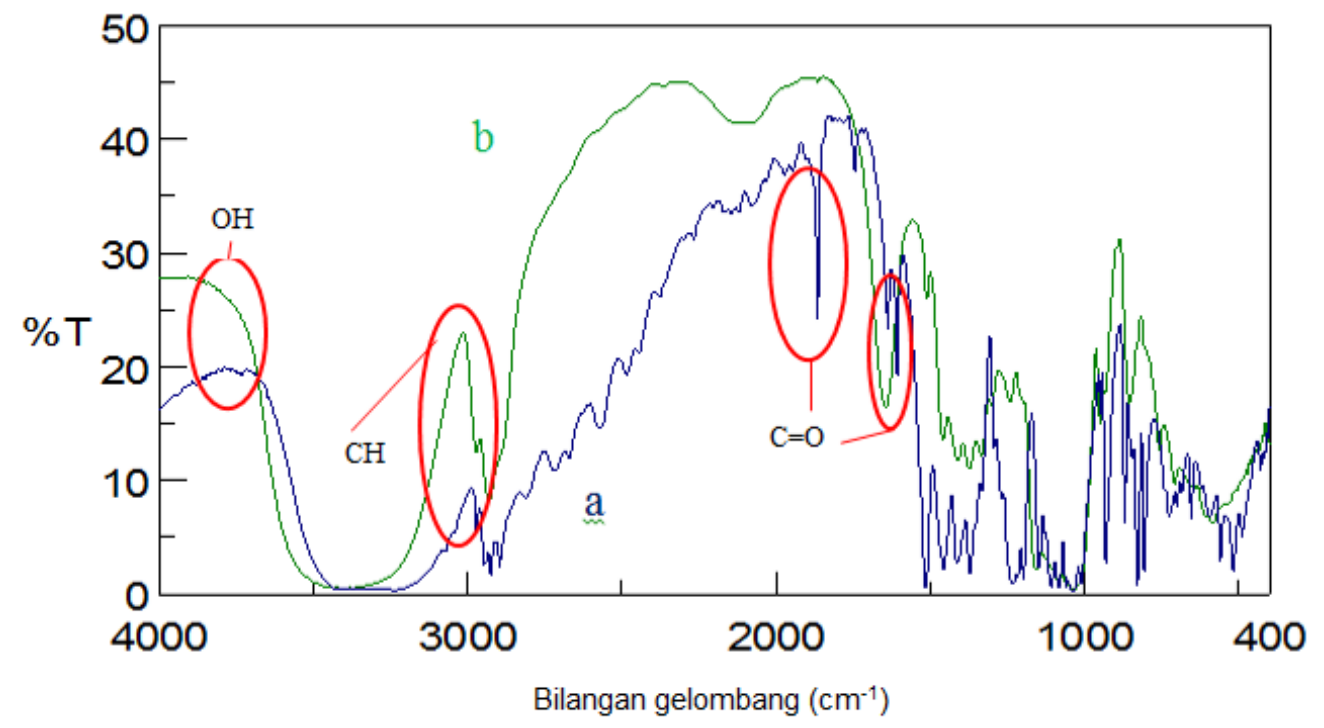

Gambar 4. Spektrum FTIR dari alfa arbutin (a) dan HPBCD (b)

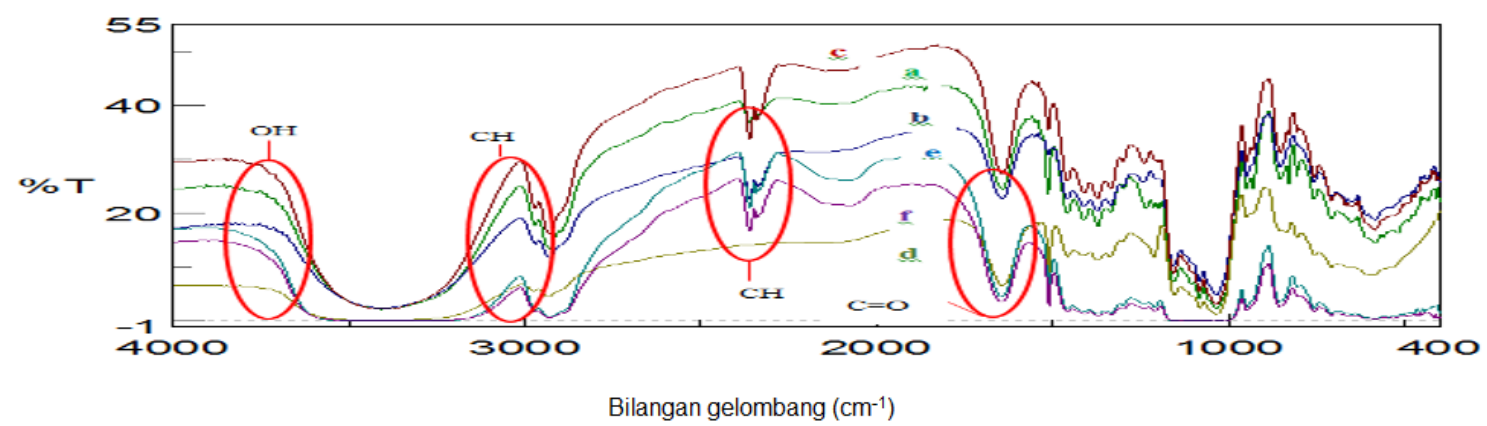

Gambar 5. Spektrum FTIR sample: F1 (a), F2 (b), F3 (c), F4 (d), F5 (e), dan F6 (f) 


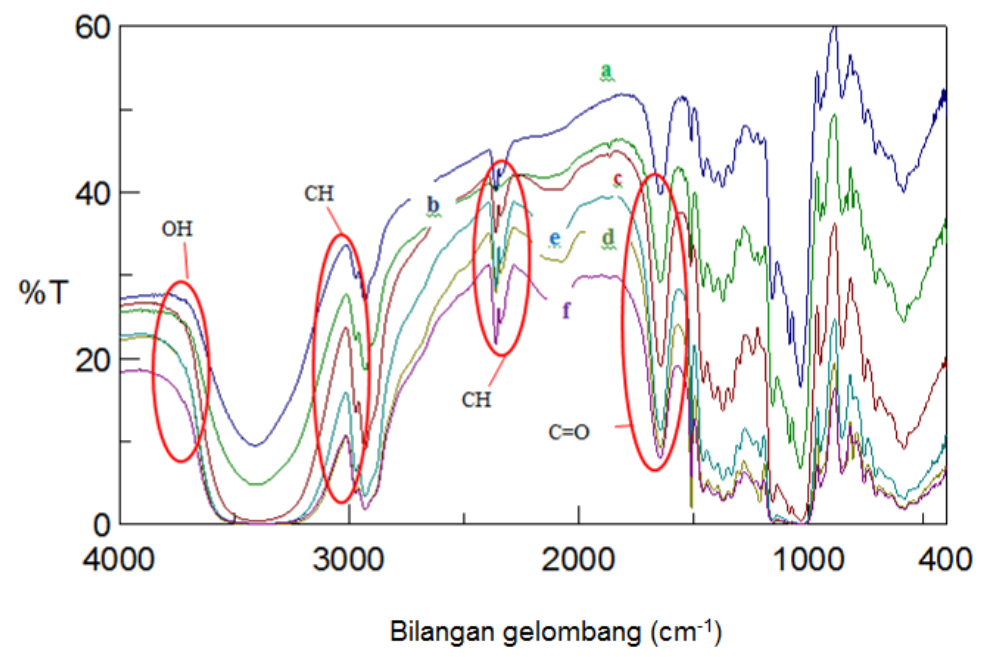

Gambar 6. Spektrum FTIR sampel pada uji stabilitas dipercepat: F1 (a), F2 (b), F3 (c), F4 (d), F5 (e), dan F6 (f)
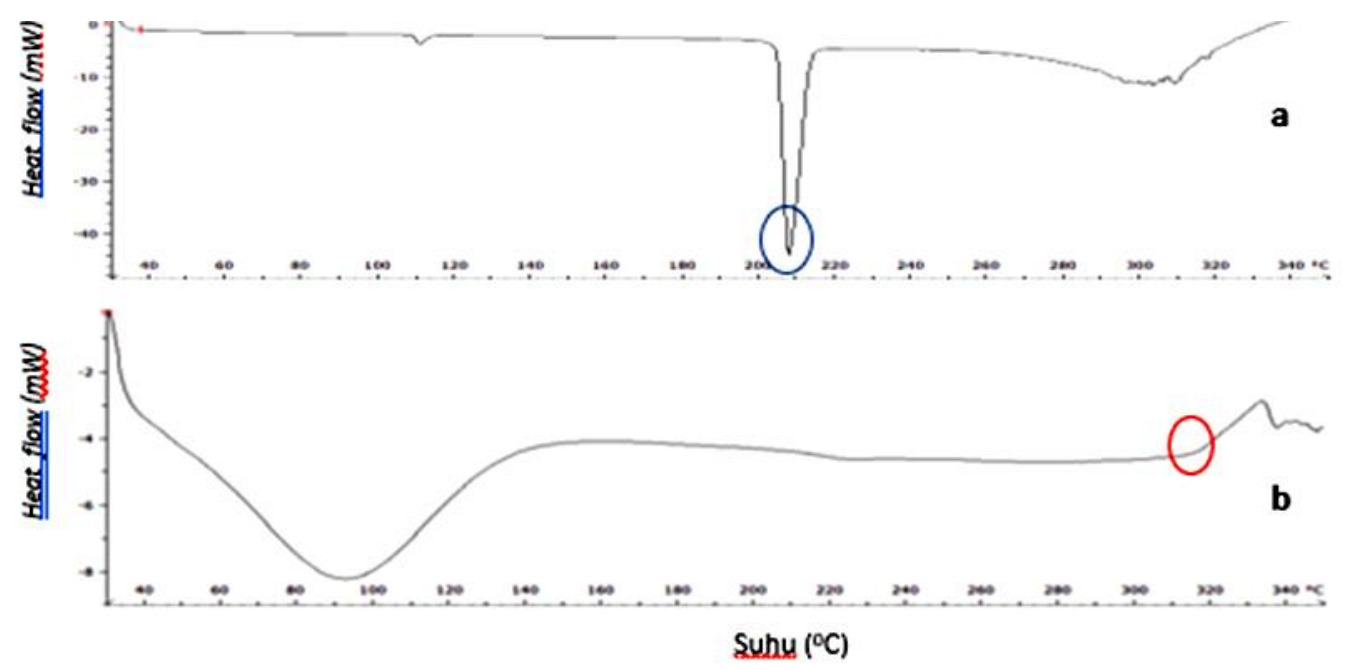

Gambar 7. Thermogram alfa arbutin (a) dan HPBCD (b)

Hal tersebut menunjukkan titik lebur HPBCD di atas alfa arbutin.

Thermogram sampel F1-F6 (Gambar 8) menunjukkan bahwa campuran fisik F1-F3 masih menunjukkan adanya dekomposisi dari alfa arbutin pada suhu sekitar 200 dan $250^{\circ} \mathrm{C}$, sedangkan komplek inklusi F4-F6 menunjukkan tidak adanya dekomposisi dari alfa arbutin. Hal tersebut menunjukkan bahwa komplek inklusi mampu melindungi alfa arbutin terhadap pemanasan pada DSC selama analisa berlangsung (40-400 ${ }^{\circ} \mathrm{C}$ ). Thermogram komplek inklusi mirip dengan thermogram HPBCD. Kecenderungan kemiripan tersebut mendukung adanya keberhasilan pembentukan komplek inklusi [6].
Thermogram sampel pada uji stabilitas dipercepat (Gambar 9), menunjukkan bahwa untuk campuran fisik F1-F3 mengalami dekomposisi pada suhu 180 dan $185^{\circ} \mathrm{C}$. Hal tersebut disebabkan oleh alfa arbutin yang mengalami peruraian. Sementara itu, komplek inklusi F4-F6 cukup stabil dan hanya mengalami peruraian pada suhu sekitar $300^{\circ} \mathrm{C}$ untuk sampel F5 dan F6.

\subsubsection{Kadar alfa arbutin dan hidrokinon}

\subsubsection{Penentuan $\lambda$ maksimum dan fase gerak}

Profil spektrum absorbansi menunjukkan bahwa $\lambda$ maksimum alfa arbutin dan hidrokinon adalah $221 \mathrm{~nm}$ (Gambar 10). Pemilihan fase gerak yang tepat dilakukan agar diperoleh kro- 


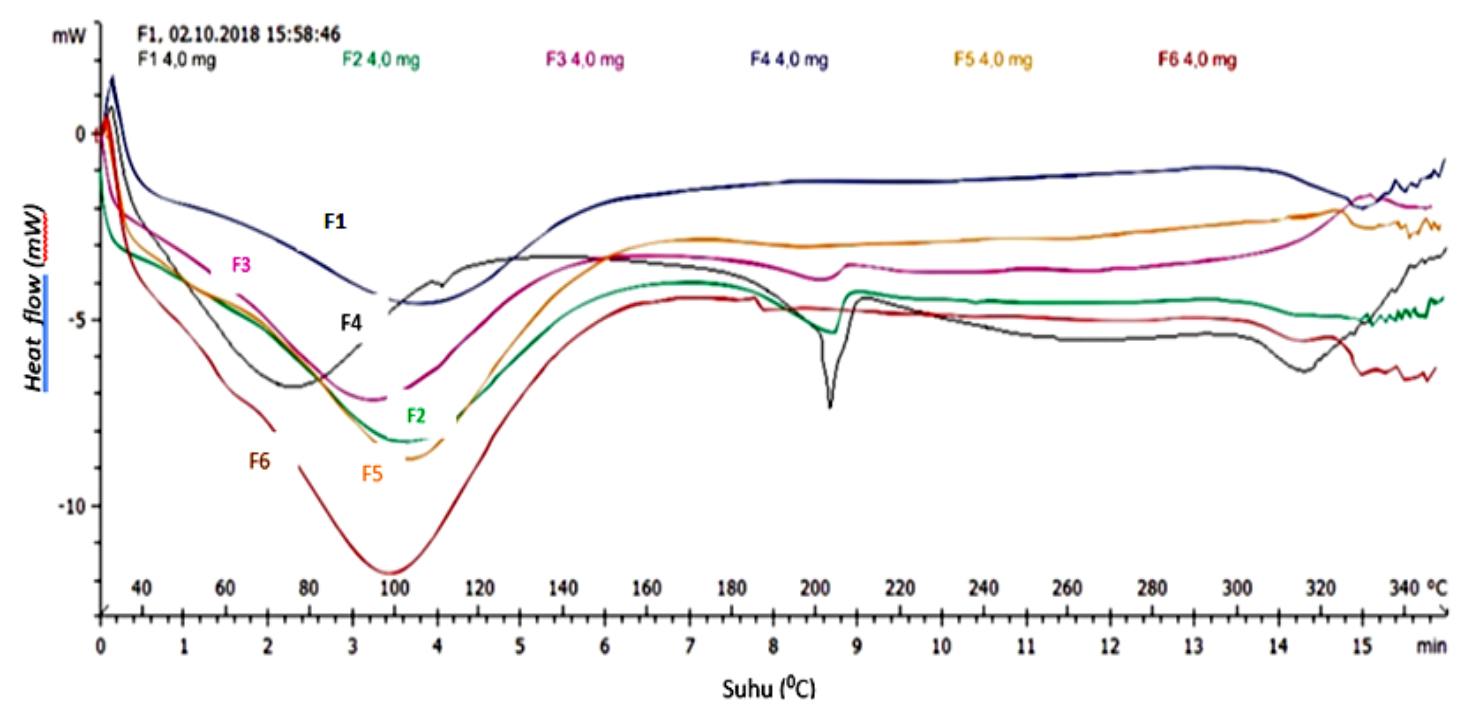

Gambar 8. Thermogram sampel karakterisasi F1-F6

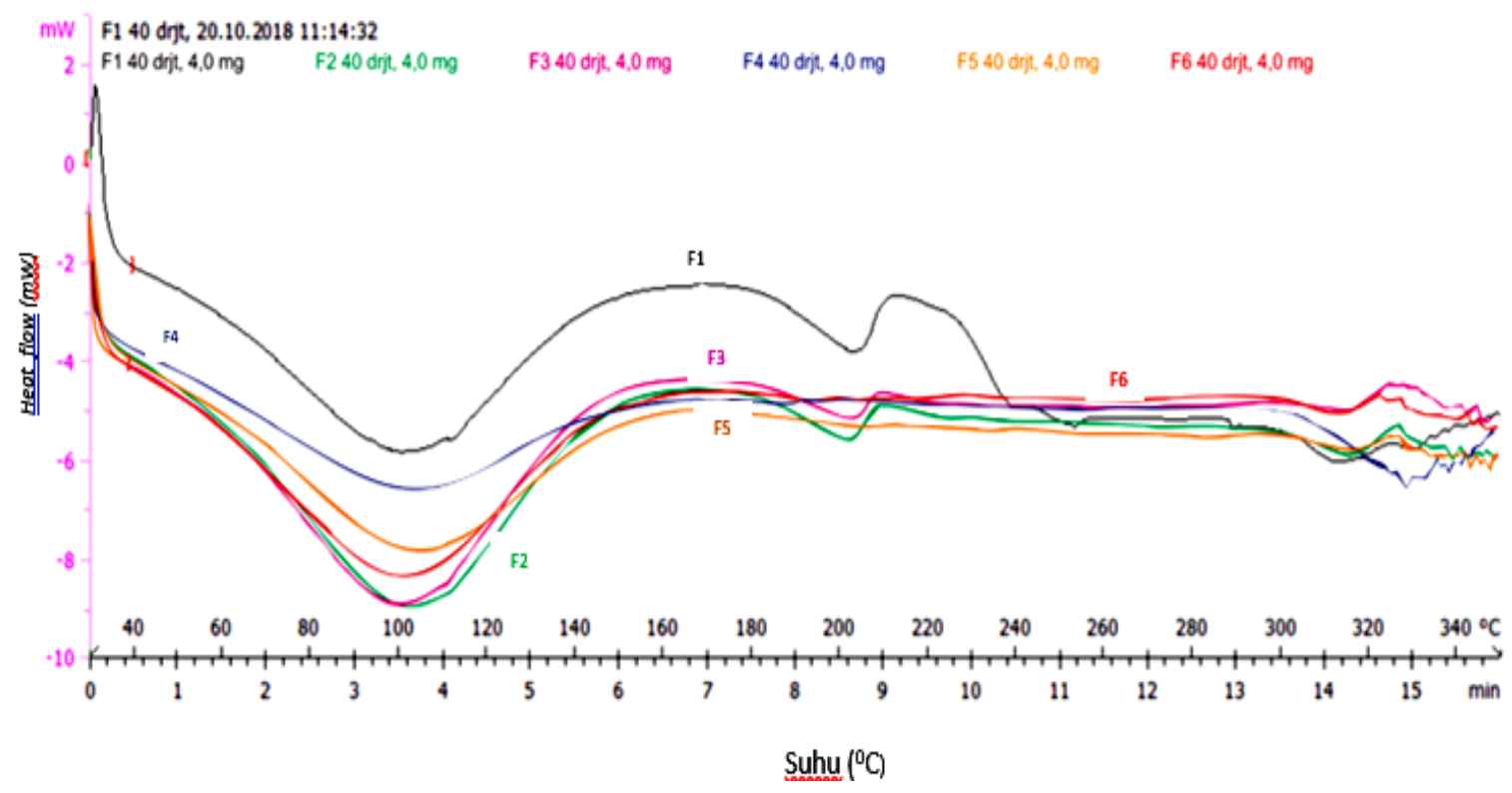

Gambar 9. Thermogram uji stabilitas dipercepat F1-F6

matogram alfa arbutin yang terpisah dengan hidrokinon. Hasil analisis alfa arbutin dengan UPLC menggunakan berbagai komposisi fase gerak pada laju alir $0,2 \mathrm{ml} /$ menit dapat dilihat pada Tabel 3. Berdasarkan tabel tersebut dipilih kondisi no.2 karena kromatogram alfa arbutin dan hidrokinon dapat terpisah sempurna.

\subsubsection{Uji kesesuaian sistem}

Uji kesesuaian sistem dilakukan untuk memberikan jaminan bahwa sistem kromatografi yang digunakan akan bekerja dengan baik selama analisis berlangsung. Uji kesesuaian sistem dilakukan pada larutan standar yang mengandung alfa arbutin dan hidrokinon dengan konsentrasi masing-masing sebesar $5,0 \mu \mathrm{g} / \mathrm{ml}$ dan dilakukan sebanyak 6 kali injeksi ke dalam sistem UPLC dengan volume 1,4 $\mu \mathrm{l}$. Hasil uji kesesuaian sistem (Tabel 4) memenuhi standar [7].

\subsubsection{Validasi metode analisa}

Hasil validasi metode analisa (Tabel 5) menunjukkan bahwa semua parameter validasi memenuhi standar dan hal ini mengindikasi- 


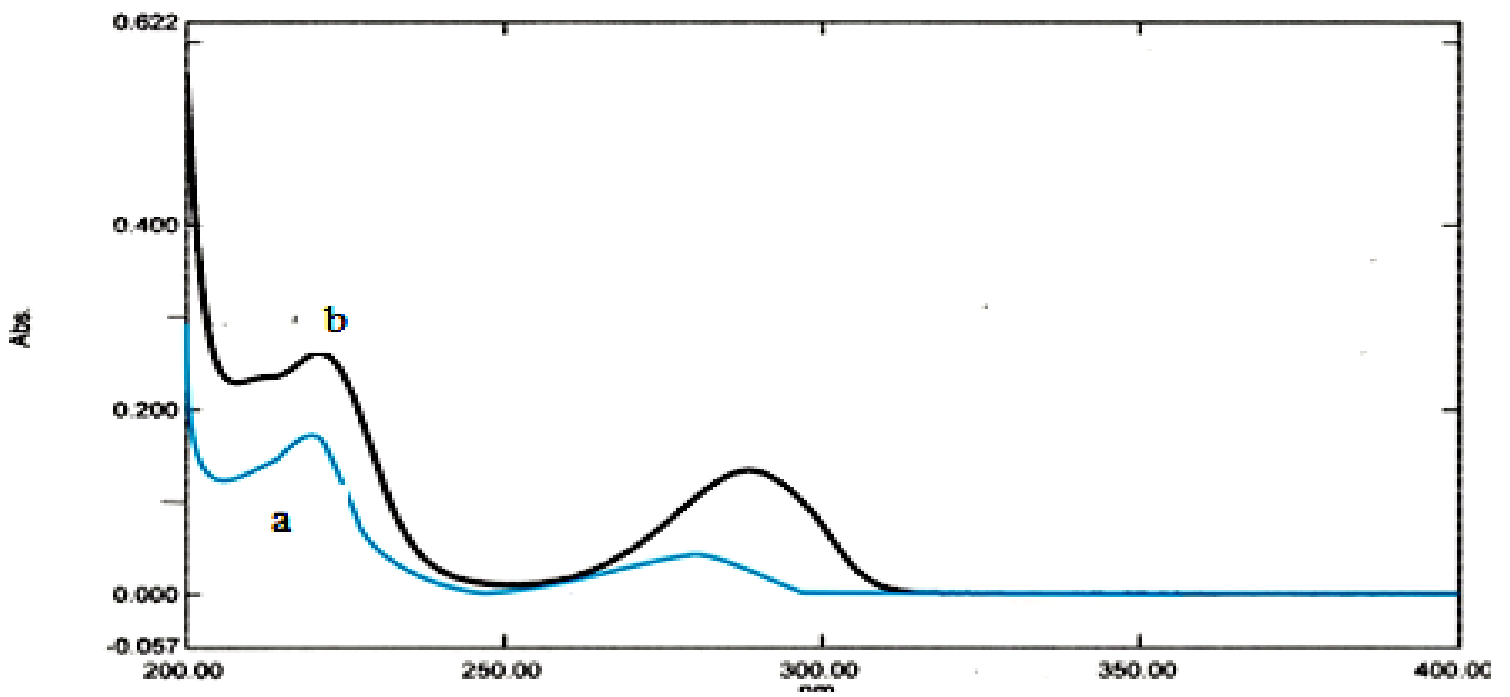

Gambar 10. Spektrum UV-VIS larutan alfa arbutin (a) dan hidrokinon (b) pada panjang gelombang $200-400 \mathrm{~nm}$

Tabel 3. Hasil analisis alfa arbutin dan hidrokinon pada berbagai fase gerak dengan laju alir $0,2 \mathrm{ml}$ menit

\begin{tabular}{|c|c|c|c|c|c|c|c|c|}
\hline \multirow[b]{2}{*}{ No. } & \multirow[b]{2}{*}{ Fase Gerak } & \multicolumn{2}{|c|}{ Waktu retensi (menit) } & \multirow{2}{*}{$\begin{array}{l}\text { Resolusi } \\
\text { (Rs) }\end{array}$} & \multicolumn{2}{|c|}{ Lempeng teoritis $(\mathrm{N})$} & \multicolumn{2}{|c|}{ Tailing factor (TF) } \\
\hline & & $\begin{array}{l}\text { Alfa } \\
\text { arbutin }\end{array}$ & Hidrokinon & & $\begin{array}{l}\text { Alfa } \\
\text { arbutin }\end{array}$ & Hidrokinon & $\begin{array}{l}\text { Alfa } \\
\text { arbutin }\end{array}$ & Hidrokinon \\
\hline 1 & $\begin{array}{l}\text { Air suling:0,1 M } \\
\mathrm{HCl} \text { :metanol } \\
(89: 1: 10)\end{array}$ & 0,61 & - & 1,2 & $\begin{array}{l}133956, \\
00\end{array}$ & - & 2,1 & - \\
\hline 2 & $\begin{array}{l}\text { Air suling: } 0,1 \mathrm{M} \\
\text { asam asetat } \\
\text { glasial:metanol } \\
(89: 1: 10)\end{array}$ & 1,289 & 1,625 & 5,14 & 5981,48 & 6084,00 & 1,16 & 1,12 \\
\hline
\end{tabular}

Tabel 4. Hasil uji kesesuaian sistem

\begin{tabular}{lllll}
\hline \multirow{2}{*}{ No. } & Parameter & Standar & Hasil & Hidrokinon \\
\cline { 4 - 5 } & & $<2$ & Alfa arbutin & 0,40 \\
\hline 1 & Simpangan baku relatif (RSD, \%) & $\leq 2$ & 0,40 & 1,1 \\
2 & Tailing factor (TF) & $>2000$ & 6008 & 6099 \\
\hline 3 & Jumlah lempeng teoritis (N) & $>2$ & 5,14 & \\
\hline
\end{tabular}

kan bahwa metode tersebut valid [8,9]. Akurasi dan presisi dilakukan pada sampel F5 yang ditambah larutan standar yang diketahui konsentrasinya. Kromatogram tidak menunjukkan adanya hidrokinon yang merupakan hasil urai alfa arbutin, sehingga dapat disimpulkan bahwa hidrokinon tidak terbentuk pada komplek inklusi tersebut.

\subsubsection{Pengujian sampel}

Kadar alfa arbutin baik pada sampel maupun pada uji stabilitas dipercepat dihitung berdasarkan persamaan regesi (Tabel 5). Kadar alfa arbutin pada sampel F1, F2, F3, F4, F5, dan F6 berturut-turut adalah $45,46,46,40,23$, dan $48 \%$, sedangkan pada hasil uji stabilitas dipercepat F1, F2, F3, F4, F5, dan F6 masing-masing 
Tabel 5. Hasil validasi metode analisa

\begin{tabular}{lllll}
\hline No. & Parameter & Standar & Hasil & Hidrokinon \\
\cline { 5 - 5 } & & & & \\
\hline 1 & Linearitas: & - & $\mathrm{y}=7935,9 \mathrm{x}+35658$ & $\mathrm{y}=14364 \mathrm{x}+64996$ \\
& Persamaan regresi & $>0,99$ & 1,00 & 0,99 \\
& Koefisien regresi $(\mathrm{r})$ & $80-110$ & $96-105$ & - \\
\hline 2 & Akurasi: RSD $(\%)$ & $\leq 2$ & 2 & - \\
\hline 3 & Presisi: $\mathrm{RSD}(\%)$ & - & 25 & 25 \\
\hline 4 & LOD $(\mu \mathrm{g} / \mathrm{ml})$ & - & 76 & 77 \\
\hline 5 & LOQ $(\mu \mathrm{g} / \mathrm{ml})$ & & & \\
\hline
\end{tabular}

Tabel 6. Hasil validasi metode analisa uji disolusi

\begin{tabular}{lllll}
\hline \multirow{2}{*}{ No. } & Parameter & Standar & Hasil & \\
& & & Alfa arbutin & Hidrokinon \\
\hline 1 & Linearitas: & - & $\mathrm{y}=24015 \mathrm{x}+9675,8$ & $\mathrm{y}=13880 \mathrm{x}+9,9$ \\
& Persamaan regresi & $>0,99$ & 1,000 & 0,999 \\
& Koefisien regresi $(\mathrm{r})$ & $80-110$ & $84-92$ & - \\
\hline 2 & Akurasi: $\mathrm{RSD}(\%)$ & $\leq 7,3$ & 4 & - \\
3 & Presisi: $\mathrm{RSD}(\%)$ & - & 31 & 32 \\
\hline 4 & LOD $(\mu \mathrm{g} / \mathrm{ml})$ & - & 93 & 96 \\
\hline 5 & LOQ $(\mu \mathrm{g} / \mathrm{ml})$ & & & \\
\hline
\end{tabular}

adalah $34,34,45,38,21$, dan 44\%. Hasil analisis statistik dengan ANOVA menunjukkan nilai $\mathrm{F}_{\text {hitung }} 5,28$ lebih besar dari $\mathrm{F}_{\text {tabel }}(5,05)$ dengan selang kepercayaan $(\alpha=0,05)$. Hal ini menunjukkan adanya perbedaan bermakna di antara keenam formula tersebut (F1-F6). Untuk mengetahui formula manakah yang memberikan perbedaan, maka dilakukan uji BNT. Hasil uji BNT menunjukkan adanya perbedaan yang nyata pada formula F6. Hal tersebut menunjukkan bahwa formula dengan komposisi perbandingan molar $1: 2$ pada komplek inklusi, kadar alfa arbutinnya lebih baik daripada formula lainnya. Kadar alfa arbutin pada F5 sangat rendah disebabkan konsentrasi alfa arbutin yang besar tidak sesuai konsentrasi HPBCD yang tersedia, sehingga alfa arbutin sulit masuk untuk berikatan dengan gugus hidrofobik pada rongga HPBCD. Hasil ANOVA terhadap uji stabilitas dipercepat didapatkan $\mathrm{F}_{\text {hitung }}(1,93)$ lebih kecil daripada $\mathrm{F}_{\text {tabel }}(6,61)$. Hal ini menunjukkan tidak ada perbedaan bermakna pada sampel maupun hasil uji stabilitas dipercepat. Hal tersebut mengindikasikan bahwa penyimpanan pada uji stabilitas dipercepat $\left(40^{\circ} \pm 2^{\circ} \mathrm{C}\right.$, RH $75 \pm 5 \%$ selama 30 hari) tidak mempengaruhi kadar alfa arbutin.

\subsubsection{Uji Disolusi}

Hasil validasi metode analisa untuk uji disolusi memenuhi standar dan dapat dilihat pada Tabel 6 [9]. Kromatogram hidrokinon tidak ditemukan pada sampel disolusi F1-F6, baik pada sampel karakterisasi maupun uji stabilitas dipercepat, yang menunjukkan bahwa alfa arbutin tidak me-ngalami peruraian. Profil disolusi alfa arbutin baik pada sampel karakterisasi maupun uji stabilitas dipercepat dapat dilihat pada Gambar 11 dan 12 .

Profil disolusi sampel karakterisasi (Gambar 11) menunjukkan bahwa campuran fisik (F1-F3) memiliki laju disolusi lebih lambat dibandingkan 


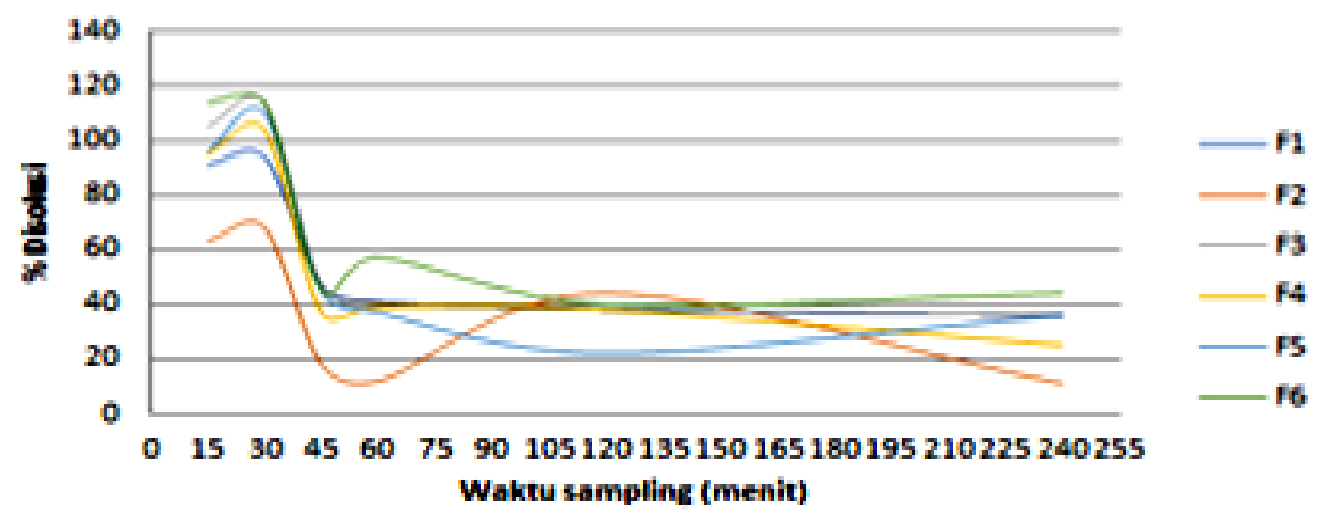

Gambar 11. Profil disolusi alfa arbutin (sampel karakterisasi)

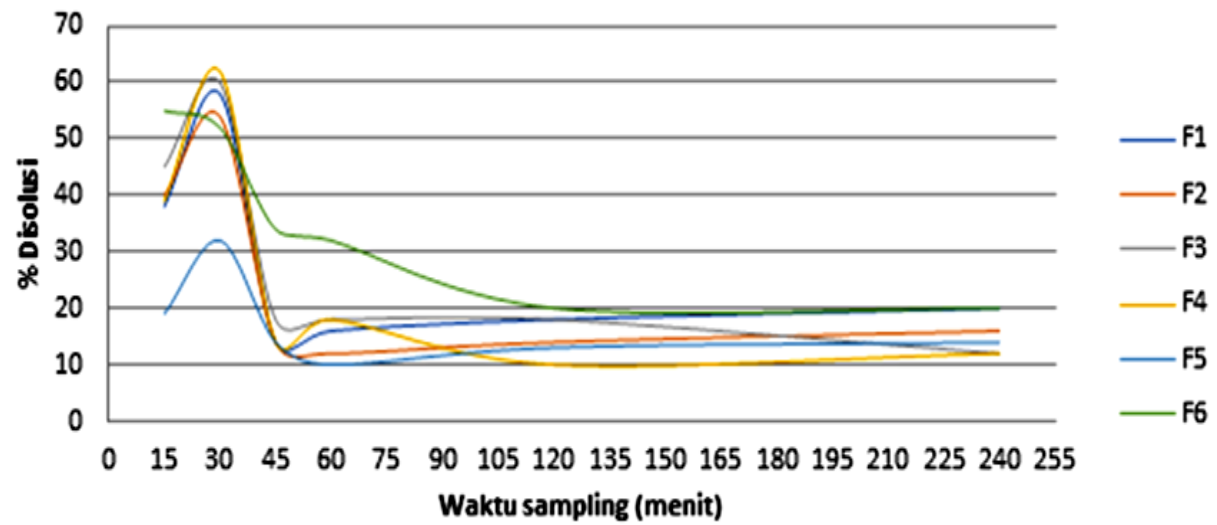

Gambar 12. Profil disolusi alfa arbutin (sampel uji stabilitas dipercepat)

dengan komplek inklusinya (F4-F6). Peningkatan persen disolusi dari komplek inklusi disebabkan oleh alfa arbutin yang terjerap ke dalam matrik HPBCD yang berbentuk rongga dimana bagian dalam rongga bersifat hidrofobik dan bagian luar bersifat hidrofilik. Persen terdisolusi yang paling tinggi adalah komplek inklusi F6 (1:2), karena semakin banyak jumlah polimer HPBCD yang digunakan maka persentase disolusi akan semakin meningkat [10].

Profil disolusi sampel uji stabilitas (Gambar 12) menunjukkan bahwa baik campuran fisik (F1-F3) maupun komplek inklusinya (F4-F6) mengalami penuruan laju disolusi. Kadar alfa arbutin yang terdisolusi pada setiap waktu dihitung menggunakan persamaan regresi dari kurva kalibrasi. Hasil ANOVA terhadap formula F1-F6 didapatkan nilai $\mathrm{F}_{\text {hitung }}(52,38)$ lebih besar daripada $F_{\text {tabel }}(2,38)$ pada $\alpha=0,05$, yang menunjukkan terdapat perbedaan bermakna pada formula F1-F6. Hasil uji BNT menunjukkan formula F6 adalah formula terbaik dibandingkan formula lainnya.

Hasil ANOVA terhadap perlakuan waktu sampling, didapatkan $\mathrm{F}_{\text {hitung }}(15,11)$ lebih besar daripada $\mathrm{F}_{\text {tabel }}(1,97)$ pada $\alpha=0,05$, yang menunjukkan ada perbedaan bermakna pada waktu sampling 15-240 menit. Uji BNT menunjukkan bahwa menit ke-30 merupakan waktu sampling yang terbaik. Hal tersebut dikarenakan alfa arbutin mudah larut dalam air sehingga tidak dibutuhkan waktu lama untuk mengalami dispersi ke dalam bentuk larutan melalui media disolusi.

\section{Kesimpulan}

Berdasarkan penelitian yang telah dilakukan dapat disimpulkan bahwa dengan metode kneading dapat dibentuk komplek inklusi alfa arbutin dan HPBCD. Komplek inklusi yang terbaik secara berurutan adalah pada variasi molar alfa arbu- 
tin dan HPBCD 1:2, 1:1 dan 2:1. Penyimpanan selama 30 hari pada suhu $40^{\circ} \pm 2^{\circ} \mathrm{C}$ dan kelembaban $75 \% \pm 5 \%$, tidak berpengaruh pada stabilitas fisikokimia baik pada campuran fisik maupun komplek inklusinya.

\section{Daftar Pustaka}

1. Degen GH. Opinion of the Scientific Committee on Consumer safety (SCCS)-Opinion on the safety of the use of $\alpha$-arbutin in cosmetic products. Regulatory Toxicology and Pharmacology. 2016;74:75-6.

2. Li Y, Li F, Cai H, Chen X, Sun W, Shen W. Structural characterization of inclusion complex of arbutin and hydroxypropyl- $\beta$-cyclodextrin. Tropical Journal of Pharmaceutical Research. 2016;15(10):2227-33.

3. ShuklaVikesh M, Ashok A. ManviFakkirappa. $\mathrm{V}$,'Influence of $ß$-cyclodextrincomplexation on ketoprofen release from matrix formulation". International Journal of Pharmaceutical Sciences and Drug Research. 2009;1(3):195-202.
4. Agustin R, Lestari FI, Halim A. Pembentukan dan karakterisasi kompleks inklusi fenilbutazon dan $\beta$-siklodekstrin dengan metoda co-grinding. Kartika: Jurnal Ilmiah Farmasi. 2015;3(1):14-9.

5. Asra A. Statistik terapan: untuk pembuat kebijakan dan pengambil keputusan, Edisi 2. Jakarta: In Media; 2014.

6. Pavia DL, Lampman GM, Kriz GS, Vyvyan JA. Introduction to spectroscopy, 5 th edition. Stamford: Cengage Learning; 2015.

7. Snyder LR, Kirkland JJ, Dolan JW. Introduction to modern liquid chromatography, 3rd edition. New Jersey: John Wiley \& Sons; 2010.

8. AOAC Official Methods of Analysis. Appendix F: Guidelines for standard method performance requirements; 2016.

9. Rochman A. Validasi dan Penjaminan Mutu Metode Analisis Kimia. Yogyakarta: UGM Press; 2016.

10. Patil JS, Kadam DV, Marapur SC, Kamalapur MV. Inclusion complex system; a novel technique to improve the solubility and bioavailability of poorly soluble drugs: a review. Int J Pharm Sci Rev Res. 2010;2(2):29-33. 